\title{
Extending the Role of Diffusion of Innovation Theory (DOI) in Achieving the Strategic Goal of the Firm With the Moderating Effect of Cost Leadership
}

\author{
Bader Abdulrahman Alyoubi, University of Jeddah, Saudi Arabia \\ Mohammad Ali Yamin, University of Jeddah, Saudi Arabia \\ (iD https://orcid.org/0000-0002-6944-6866
}

\begin{abstract}
The information system literature has long emphasized the importance of employee acceptance of information technology for achieving the strategic goal of the firm and organizational performance. Consequently, this study investigates the determinants of acceptance of information technology with the extension of diffusion of innovation theory (DOI) in organizational context. Results showed that compatibility, innovativeness, trust in technology, perceived gap in IT capabilities, employee selfefficacy, and perceived cost advantage explained $\mathrm{R}^{\wedge} 279.4 \%$ variance in achieving strategic goal of the firm. The effect size analysis showed that perceived gap in IT capabilities had substantial effect size. Similarly, substantial predictive relevance was found $\mathrm{Q}^{\wedge} 258.1 \%, 15.7 \%$ when predicting firm strategic goals and organizational performance, respectively.
\end{abstract}

\section{KEYWORDS}

Compatibility, Cost Leadership, Employee Self-Efficacy, Innovativeness, Moderating Analysis, Structural Equation Modeling

\section{INTRODUCTION}

In this vibrant economy, the use of information technology is considered essential for organizational operations. Despite impressive advances in technology, the problem of underutilization of technology in human resource organizations is still existed. In developing countries the use of information technology is complex and crucial (Omamo, Rodrigues, \& Muliaro, 2020). Therefore, understanding the IT determinants influence on employee performance and organizational performance is important. The present study fills the gap in information system and human resource literature by developing and amalgamated model which combines employee psychological and technological factors in achieving strategic goal and performance of the firm. In technology context, the diffusion of innovation theory (DOI) is extended with trust in technology, perceived gap in IT capabilities, employee self-efficacy, perceived service quality and perceived cost advantage in order to see the impact of these factors on achieving strategic goal of the firm. To the date, this study is the first that investigates the role of diffusion of innovation theory in achieving strategic goal of the firm and organizational performance.

DOI: 10.4018/IJSDA.20211001.oa15

This article published as an Open Access article distributed under the terms of the Creative Commons Attribution License (http://creativecommons.org/licenses/by/4.0/) which permits unrestricted use, distribution, and production in any medium, provided the author of the original work and original publication source are properly credited. 
Diffusion of innovation theory was introduced by Rogers (2003) which includes two factors namely; compatibility and innovativeness. Earlier studies had confirmed the importance of compatibility and innovativeness in acceptance and usage of information technology (Rogers, 1962, 2003; Ryan \& Gross, 1943). Concerning with other constructs such as trust in technology, perceived gap in IT capabilities, employee self-efficacy, perceived service quality and perceived cost advantage are studied by several researcher in technology adoption context (Bose \& Luo, 2011; Daud Norzaidi, Choy Chong, Murali, \& Intan Salwani, 2007; Ghani, Rahi, Yasin, \& Alnaser, 2017; Han, 2003; Ho Cheong \& Park, 2005; Lee \& Kim, 2007; Liang, Saraf, Hu, \& Xue, 2007; R. Samar \& Mazuri, 2019b; Teo, 2010; Wixom \& Todd, 2005; Wu, Mahajan, \& Balasubramanian, 2003). Therefore, this study contributes to the body of knowledge by examining these constructs in achieving strategic goal of the firm which in turn enhance organizational performance. Trust in technology is referred to employee perception about technology that how technology protect monetary and confidential information at organizational level (S Rahi, Ghani, \& Muhamad, 2017). Author like Xin and Levina (2008) stated that organizations achieve strategic goals by gaining IT knowledge through the deployment of technology. According to D. Wang, Xu, and Chan (2008) postulated that self-efficacy effect positively on employee behavioral intention, effort and determination to carry out a task or achieving strategic goal of a firm and organizational performance. Similarly, Ghani et al. (2017) asserted that service quality bring ease in employee daily work and enhance organizational performance. Aside of direct relationship among exogenous and endogenous constructs, this study includes the moderating role of cost leadership and contributes to human resource literature. The research model of this study is depicted in Fig 1. In following sections the importance of these construct is augmented.

\section{LITERATURE REVIEW}

\subsection{Diffusion of Innovation Theory (DOI)}

Diffusion of innovation theory was initially introduced by Rogers in 1962 and includes four components of technology diffusion namely communication, social system, time and innovation (Rogers, 1962). By looking at dynamic global changes Rogers revised his theory in 2003 and revealed five stages of technology diffusion which includes persuasion, implementation, decision, confirmation and knowledge (Rogers, 2003). This study focuses on compatibility and innovativeness dimensions to examine organizational goals and firm performance. Innovation is seen as the extent wherein "individual engages in activities that lead to selection either to adopt or reject an innovation" (Rogers, 1962, 2003; Ryan \& Gross, 1943). Therefore, compatibility is defined as the extent wherein "innovation is perceived as being consistent with existing values, current working practices/needs, and past experiences of potential adopters" (Nikabadi \& Hakaki, 2018; Rogers, 1962, 2003; Ryan \& Gross, 1943). Previous literature had confirmed significant impact of innovativeness and compatibility in achieving strategic goal of the firm and boosting organizational performance (Karahanna, Agarwal, \& Angst, 2006; Oliveira, Thomas, Baptista, \& Campos, 2016; Samar Rahi \& Abd. Ghani, 2018; Rogers, 1962, 2003; Zhao \& de Pablos, 2011). Thus, compatibility and innovativeness is hypothesized as:

H1: Compatibility has positive influence on achieving strategic goal of the firm.

H2: Innovativeness has positive influence on achieving strategic goal of the firm.

\subsection{Trust in the Technology (TECH)}

Trust concern has been seen major barrier in adoption and acceptance of human resource management system (Elharakany, Moscardini, Khalifa, \& Abd Elghany, 2018; Miltgen, Popovič, \& Oliveira, 2013). Trust is referred to employee perception about technology that how technology protect monetary and confidential information at organizational level (Al-Ammary, Al-Doseri, Al-Blushi, Al-Blushi, \& Aman, 2019; Mayayise \& Osunmakinde, 2019; S Rahi et al., 2017). According to Miltgen et al. (2013) 
asserted that sense of risk is associated with safety and employee trust on technology plays vital role in acceptance and usage of human resource management system. Similarly, earlier studies had confirmed that trust is an effective tool in reducing uncertainty (Al-Alawi \& Al-Bassam, 2019; Fuller, Serva, \& Baroudi, 2009; Ha \& Lo, 2018; Pavlou, 2003). With increase of trust factor, employee feels safe in daily operations which in turn help them to achieve strategic goal of the firm timely and efficiently (Fuller et al., 2009; Komiak \& Benbasat, 2006; Mohammad Ali, 2018; Pavlou, 2003; Salisbury, Pearson, Pearson, \& Miller, 2001). Therefore, and back-up by earlier studies Fuller et al. (2009); Komiak and Benbasat (2006); Miltgen et al. (2013); Pavlou (2003); S Rahi et al. (2017); Salisbury et al. (2001), researcher anticipate that employee having trust in technology feels more secure and safe and accomplish their job responsibilities efficiently. Thus, trust in technology is hypothesized as:

H3: Trust in the technology has positive influence on achieving strategic goal of the firm.

\subsection{Perceived Gap in IT Capabilities (PGIT)}

Perceived gap in IT capabilities directs to the differences between organization's own ability and solution (technology) provider capability in terms of knowledge, resources and agility in deployment and usage of management information system (Jayatilaka, Schwarz, \& Hirschheim, 2003; Loebbecke \& Huyskens, 2006). Organizations can fill the gap in IT capabilities by reviewing strategic IT knowledge, resources and agility in human resource operations (Smith \& Kumar, 2004). Author like Xin and Levina (2008) stated that organizations achieve strategic goals by gaining IT knowledge through the deployment of technology. However, if companies are incapable to respond the technological advancement, they may take help from solution provider for agile technology operations. Concerning with resources dimension in IT capabilities, resource based theory can be used. Following resource-based theory $(R B T)$ organization can evaluate their IT capabilities in order to confirm whether organization needs to outsource IT operation to external solution provider or need to use internal organizational resources to fill the technology usage gap. Similarly, Smith and Kumar (2004) postulated that with perceived gap in IT technology, organization can enhance their competitive advantage. Earlier studies have confirmed that perceived gap in IT capabilities had significant influence on achieving strategic goal of the firm Jayatilaka et al. (2003); Loebbecke and Huyskens (2006); Smith and Kumar (2004). Therefore and following above argument perceived gap in IT capabilities is hypothesized as:

H4: Perceived gap in IT capabilities has positive influence on achieving strategic goal of the firm.

\subsection{Employee Self-Efficacy (EMSE)}

In general self-efficacy is defined as " $a$ situation where individual become motivated when they believe that their effort will improve task performance" (Bandura, Freeman, \& Lightsey, 1999; Choi, 2004). According to Bandura et al. (1999) asserted that self-efficacy is actually the ability of an individual to perform a given task in order to meet situational demands within an organization. Authors like D. Wang et al. (2008) postulated that self-efficacy effect positively on employee behavioral intention, effort and determination to carry out a task or achieving strategic goal of a firm and organizational performance. Concerning with technology acceptance in organizations and employee-self-efficacy, earlier studies had confirmed a significant impact of employee self-efficacy on achieving strategic goal of the firm and firm performance (Bandura et al., 1999; Choi, 2004; D. Wang et al., 2008). Following above arguments and supported by Aldholay, Isaac, Abdullah, Abdulsalam, and Al-Shibami (2018); Bandura et al. (1999); Choi (2004); Makokha and Ochieng (2014); D. Wang et al. (2008); Y.-S. Wang and Liao (2008), employee self-efficacy is hypothesized as:

H5: Employee Self-efficacy has positive influence on achieving strategic goal of the firm. 


\subsection{Perceived Service Quality (PRSQ)}

Perceived service quality is seen as "the extent where employees believe that using a human resource management system will be free from effort and meet with their expectations to perform a task" (Delone \& McLean, 2003; Samar Rahi \& Abd. Ghani, 2018). In management information system (MIS) literature three types of service quality dimensions such as information quality, service quality and system quality are widely discussed in technology acceptance context (R. Samar \& Mazuri, 2019b). Therefore, the present study focus is on achieving strategic goal of the firm and service quality is the most important dimension to be taken into consideration. Earlier studies had confirmed positive relationship between service quality and employee willingness to achieve strategic goal of the firm (Bose \& Luo, 2011; Daud Norzaidi et al., 2007; Ghani et al., 2017; Han, 2003; Ho Cheong \& Park, 2005; Lee \& Kim, 2007; Liang et al., 2007; R. Samar \& Mazuri, 2019b; Teo, 2010; Wixom \& Todd, 2005; Wu et al., 2003). Thus, following above arguments perceived service quality is hypothesized as:

H6: Perceived service quality has positive influence on achieving strategic goal of the firm.

\subsection{Perceived Cost Advantage (PRCA)}

Perceived cost advantage is defined as, "the extent where organizations reduce operational and strategic cost using information technology" (Martens \& Teuteberg, 2012). This study evaluates two types of cost advantages foremost; the cost advantage is examined in economical perspective which is achieved using information technology. Secondly, cost advantage is studied in strategic perspective and fills the gap in IT capabilities for organization competitive advantage (Dubey \& Wagle, 2007). In economical perspective, the cost advantage is compared with internal production of the information technology (Auxilia, Raja, \& Kannan, 2020; Benlian \& Hess, 2011; Galli, 2020). Therefore, organizations may take help from external parties using outsourcing method for the deployment of information system. According to Smith and Kumar (2004) asserted that companies using high level of transactions are usually outsource their IT operation in order to achieve perceived cost advantage. Following above arguments and back-up by earlier literature Dubey and Wagle (2007); Fan, Kumar, and Whinston (2009); Limam and Boutaba (2010); Smith and Kumar (2004) perceived cost advantage is hypothesised as:

H7: Perceived cost advantage has positive influence on achieving strategic goal of the firm.

\subsection{Achieving Strategic Goal of the Firm and Organizational Performance}

In order to achieve organizational performance employee strategic goals must be aligned. According to Dobre (2013) employee motivation towards achieving strategic goal significantly contributes to organizational performance. It is that management information system in HR department is cost effectively and bring ease in employee strategic operations (Kiumarsi, Isa, Jayaraman, Amran, \& Hashemi, 2020; Venkatachalam, Fielt, Rosemann, \& Mathews, 2012). According to Dehning, Richardson, and Zmud (2007), use of technology in organizations improve employee performance and help employee to achieve goals timely and cost efficiently. Earlier studies had confirmed that employee determination to achieve firm strategic firm goals significantly impact on organizational performance (Chakraborty \& Biswas, 2019; Dobre, 2013; Kiveu, Namusonge, \& Muathe, 2019; Trybou, Gemmel, Desmidt, \& Annemans, 2017). Therefore, and supported by previous literature Chakraborty and Biswas (2019); Dobre (2013); Haselmann and Vossen (2011); Kaufmann and Schneider (2004); Mahdi and Almsafir (2014); Roper, Du, and Love (2006); Seethamraju (2015); Trybou et al. (2017); Venkatachalam et al. (2012), achieving strategic goal of the firm is hypothesized as:

H8: Achieving strategic goal of the firm has positive influence on organizational performance. 


\subsection{Moderating Role of Cost Leadership (CLED)}

The concept of cost leadership is identified as "the extent wherein company cut their operational and procurement cost thorough strategic orientation" (Porter, 1985). The importance of strategic orientation is indispensable in an organization and it helps organizations to analyze, differentiate product and services for competitive advantages (Miles, Snow, Meyer, \& Coleman Jr, 1978); Porter (1985). Authors like Aubert, Beaurivage, Croteau, and Rivard (2009) fond inconsistent relationship between cost leader ship and IT outsourcing for achieving strategic goal of the firm. Therefore, the current study examines generic cost leadership in the context of organizational performance and achieving strategic goal of the firm which is in line with Porter (1985). It is argued that organizations with strong cost leadership enhance positive relationship in achieving strategic goal of the firm and organizational performance (Grover, Cheon, \& Teng, 1994). Extending to this Heart, Pliskin, and Tractinsky (2004) postulated that strategic orientation towards cost leadership improve business performance. Following above arguments and supported by Heart et al. (2004); Miles et al. (1978); Porter (1985), cost leadership is hypothesized as:

H9: The positive relationship between achieving strategic goal of the firm and organizational performance will be stronger when cost Leadership is higher.

\section{METHODOLOGY}

\subsection{Scale Development}

The present study is quantitative in nature and followed positivist paradigm. Following the theme of this research a survey questionnaire is developed to collect the respondent observations. Survey questionnaire of this study is in twofold. In first section it contains demographic information of the respondents such as age, gender, education and marital status. In following section scales items are demonstrated. The context of this study is to investigate organizational strategic goal and organizational performance of the firm with technology factors such as trust in technology, compatibility and innovativeness. Thus, scale items were adopted from previous literature and then adapted into current research context. Scale items for the constructs achieving strategic goal of the firm and organizational performance were adopted from Chakraborty and Biswas (2019). Therefore, instrument items for the construct compatibility and innovativeness were adopted form Samar Rahi and Abd. Ghani (2018) and then adapted into current research context. Scale items for the construct of perceived cost advantage adopted from Smith and Kumar (2004). Similarly, perceived gap in IT capabilities adapted from Jayatilaka et al. (2003). Cost leadership items were adapted from Miles et al. (1978) and Porter (1985). Finally, perceived service quality, employee self-efficacy and trust items were adapted from Samar Rahi and Abd. Ghani (2019a); R. Samar and Mazuri (2019b) and S Rahi et al. (2017). All constructs items are measured using a seven-point Likert scale ranging from " 1 " strongly disagree to “7” strongly agree which is in line with earlier studies (Samar Rahi, 2016b; S Rahi \& Ghani, 2016). The process of data collection and sample size of this study is demonstrated in following section.

\subsection{Data Collection Methods and Sampling}

In order to examine firm strategic goal and organizational performance, a research survey is conducted towards Public sector organizations in Saudi Arabia. Employees of the public sector organizations were the main respondents in this study. This is due to the fact that public sector organizations in Saudi Arabia are still in initial phase of technology adoption especially in human resource sector (Mohammad Ali Yamin \& Swaiess, 2019).Thus, it is expected that employees of the public sector organizations can better explain diffusion of technology in Saudi organizations. For sampling, G-Power software was used to calculate the sample size (Samar Rahi, Alnaser, \& Ghani, 2019). Findings of 
Figure 1. Research framework of the study

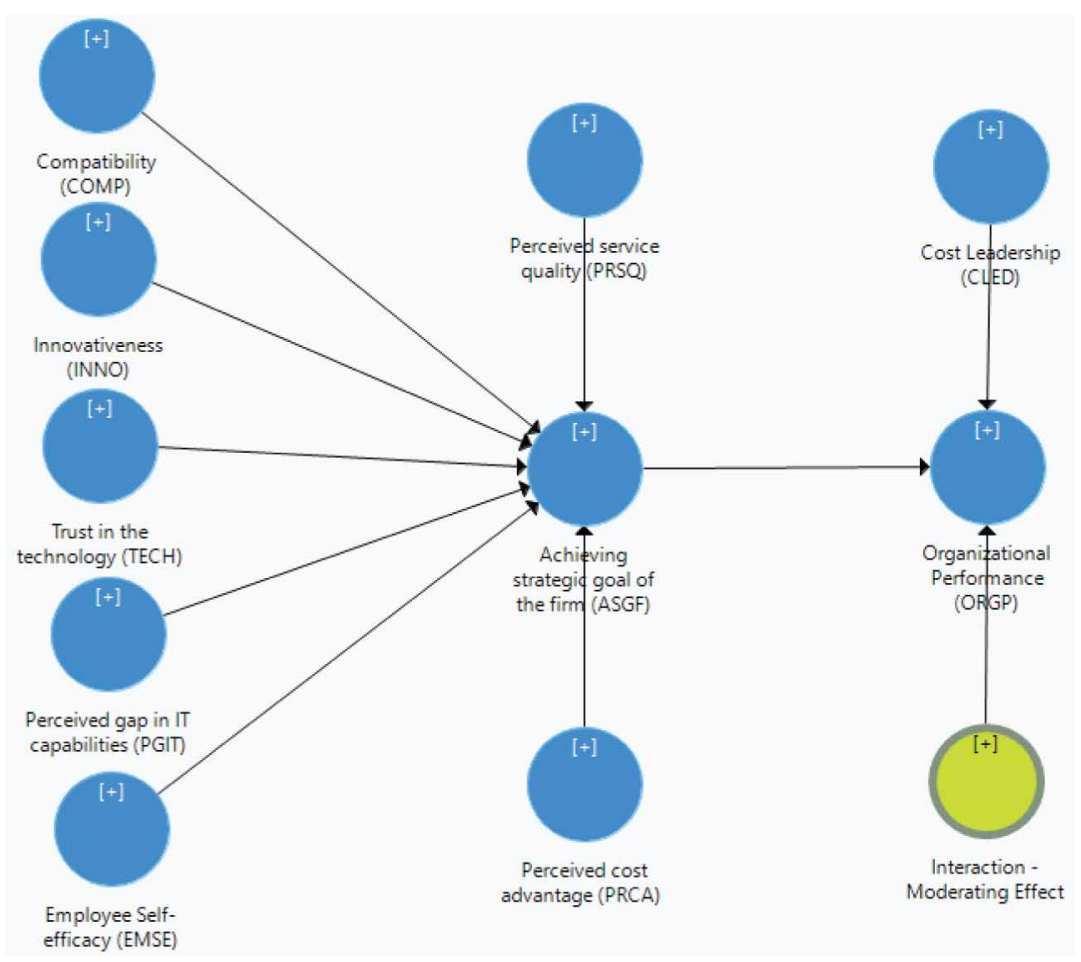

the G-power software revealed that for factor analysis a sample of 200 respondents is substantial. Therefore, addition in sample size mitigate sampling error (Samar Rahi \& Ghani, 2018b). Thus, the current study distributes 400 questionnaires to public sector organizations using convenience sampling approach (Samar Rahi, 2018). Convenience sampling approach is the most appropriate approach in data collection in management sciences studies (Samar Rahi \& Ghani, 2018a). The employees of public sector organizations were requested to fill the questionnaires and returned to researcher in said time. Amongst 400, 360 valid questionnaires were returned to the researcher that further used for structural equation modeling.

\subsection{Harman's Single Factor Test}

This study collects empirical data using single source method for endogenous and exogenous variables. Therefore, it may affect due to common method variance bias. Testing common method variance bias is necessary before structural equation modeling (FMI Alnaser, Ghani, \& Rahi, 2017). Thus, Harman's single factor test is incorporated to see common method variance bias (F Alnaser, Ghani, \& Rahi, 2018; Mohammad Ali, 2018). Harman's single factor test suggested that the maximum covariance explained by single factor should be less than 50\%. Therefore, the findings of Harman's single factor test showed that the maximum co-variance explained by first factor was less than $50 \%$. These findings confirmed that common method variance is not likely issue in this study and data is appropriate for inferential analysis using structural equation modeling. 


\section{DATA ANALYSIS AND RESULTS}

This study extends the diffusion of innovation theory (DOI) with some other technology factors namely; trust in technology, perceived gap in IT technology and perceived services quality to investigate firm strategic goals and firm performance. Therefore, structural equation modeling (SEM) technique is the most appropriate approach for data analysis. Structural equation modeling is defined as "a statistical technique for testing and estimating causal relations using a combination of statistical data and qualitative causal assumptions" (Samar Rahi, Ghani, \& Ngah, 2020). The structural equation modeling approach incorporated measurement model and structural model. For structural model estimation Smart PLS 3.2.7 software is used (S. Rahi, 2017; Ringle, Wende, \& Becker, 2015).

\subsection{Measurement Model}

The measurement model estimates convergent validity and discriminant validity of the constructs. The convergent validity of the model is achieved with construct reliability, indicator validity and average variance extracted. In order to achieve construct reliability the criterion is that the values of Cronbach's alpha and composite reliability should be higher than 0.70 indicating adequate reliability of the constructs. Therefore, for indicator reliability, the values of factor loadings should be higher than 0.60 as suggested by Samar Rahi, Abd.Ghani, and Hafaz Ngah (2019). Finally, convergent validity of the model was achieved with average variance extracted (AVE), following criterion that average variance extracted values should be higher than 0.50 , which is in line with (Samar Rahi, 2019). Findings revealed that all values including Cronbach's alpha, composite reliability and average variance extracted are adequate and reliable for further data analysis. Table 1 depicts the values of construct reliability, indicator reliability and convergent validity of the constructs.

The second step of the measurement model is to estimate discriminant validity of the constructs. Discriminant validity is defined as the extent wherein constructs measure distinct concept (S. Rahi, 2018a). Therefore, it is necessary to confirm the discriminant validity of the constructs (Samar Rahi \& Abd. Ghani, 2019a). The current study estimates discriminant validity using Fornell and Larcker criterion, cross loadings and Heterotrait-Monotrait Ratio as suggested by S. Rahi (2018b) and Ghani et al. (2017). Fornell and Larcker criterion suggested that the square root values of average variance extracted (AVE) should be greater than corresponding constructs indicates construct is discriminant (Fornell \& Larcker, 1981). Finding of the analysis revealed that all square root values were greater than corresponding constructs values and confirmed that construct is discriminant. The values of average variance extracted (AVE) depicted in Table 2.

The discriminant validity of the constructs was tested with cross-loading method. According to Fornell and Larcker (1981) cross-loading method provide more authentic results that may dilutes in average variance extract. In order to achieve cross discriminant validity of the constructs, the criterion is that loadings should exceed than all of its loading on the other constructs (R. Samar \& Mazuri, 2019a). Findings of the cross loading method showed that all constructs loadings are higher than corresponding constructs which confirmed that construct is discriminant. The result of the cross loadings method is shown in Table 3.

In recent years authors like Gold and Arvind Malhotra (2001); Kline (2011) have criticized old dated methods such as cross loadings and Fornell and Larcker's method. According to Kline (2011) Heterotrait-monotrait ratio analysis (HTMT) is the most appropriate method to measure discriminant validity of the constructs. The study of Kline (2011) revealed that cross loading and Fornell and Larcker's methods are not sufficient to measure discriminant validity of the constructs. Thus, the current study confirms discriminant validity of the constructs using Heterotrait-monotrait ratio analysis (HTMT). In order to achieve discriminant validity of the construct the values of HTMT ration analysis should be less than 0.85 or 0.90 indicate adequate discriminant validity of the constructs (R. Samar \& Mazuri, 2019b). Table 4 depicts the values of HTMT indicated that all values of Heterotrait-monotrait ratio analysis are less than 0.85 or 0.90 , confirming adequate discriminant validity of the constructs. 


\section{Table 1. Measurement Model}

\begin{tabular}{|c|c|c|c|c|}
\hline Constructs/Items & Loadings & $(\boldsymbol{\alpha})$ & $\mathbf{C R}$ & AVE \\
\hline $\begin{array}{l}\text { ASGF1: Achieving strategic goal of the firm improves employee competency and boost organization } \\
\text { performance. }\end{array}$ & 0.853 & 0.856 & 0.912 & 0.776 \\
\hline $\begin{array}{l}\text { ASGF2: Attaining and achieving organizational goal ensures employee engagement, empowerment and } \\
\text { commitment that drive toward organizational performance. }\end{array}$ & 0.893 & & & \\
\hline $\begin{array}{l}\text { ASGF3: Integration and achievement of individual and organizational goals helps organizations to } \\
\text { manage further challenges and risks for dynamic performance. }\end{array}$ & 0.896 & & & \\
\hline
\end{tabular}

CLED1: our organization focuses more on vendor sourcing and supplier management that cut procurement costs.

CLED2: Our organization focuses more on resource efficiency and process improvements that cut operational costs.

CLED3: Our organization focuses more on cost competition that provide competitive advantage.

\begin{tabular}{|l|l|l|l|l|}
\hline 0.816 & 0.798 & 0.882 & 0.713 \\
\hline 0.834 & & & \\
\hline 0.882 & & & \\
\hline
\end{tabular}

\begin{tabular}{|c|c|c|c|c|}
\hline COMP1: Using information system fits into my job style. & 0.912 & 0.890 & 0.923 & 0.750 \\
\hline COMP2: Using information system is compatible with all aspects of my job style. & 0.838 & & & \\
\hline COMP3: Using information system is completely compatible with my current job situation. & 0.941 & & & \\
\hline COMP4: I think that using information system fits well with the way I like to accomplish my tasks. & 0.762 & & & \\
\hline $\begin{array}{l}\text { EMSE1: I feel confident in using information system sending and receiving e-mail messages creatively } \\
\text { in my organization. }\end{array}$ & 0.867 & 0.881 & 0.927 & 0.808 \\
\hline $\begin{array}{l}\text { EMSE2: In my organization I have trust in human resource management system while sending and } \\
\text { receiving e-mail messages. }\end{array}$ & 0.929 & & & \\
\hline $\begin{array}{l}\text { EMSE3: In my organization employees have confidence in their ability to solve problems using online } \\
\text { system. }\end{array}$ & 0.899 & & & \\
\hline
\end{tabular}

\begin{tabular}{|l|l|l|l|}
\hline INNO1: In my organization and peers, I am usually the first to try out new information technologies. & 0.806 & 0.809 \\
\hline INNO2: If I heard about a new information technology, I would look for ways to experiment with it. & 0.955 & 0.944 & 0.935 \\
\hline INNO3: I like to experiment with new information technologies at my job place. & 0.895 & & \\
\hline $\begin{array}{l}\text { INNO4: If I heard about a new information technology in my organization I prefer to complete my task } \\
\text { using that technology. }\end{array}$ & 0 \\
\hline
\end{tabular}

\begin{tabular}{|c|c|c|c|c|}
\hline $\begin{array}{l}\text { ORGP1: Superior performance of the organization helps employees to build skill and make the } \\
\text { organization sustainable. }\end{array}$ & 0.941 & 0.894 & 0.934 & 0.826 \\
\hline $\begin{array}{l}\text { ORGP2: Effective performance of the firm leads to quality and excellence that provide competitive } \\
\text { advantage to organization. }\end{array}$ & 0.874 & & & \\
\hline $\begin{array}{l}\text { ORGP3: Effective performance of the firm help employee to achieve firm goals and enhance firm image } \\
\text { in industry. }\end{array}$ & 0.910 & & & \\
\hline
\end{tabular}

\begin{tabular}{|c|c|c|c|c|}
\hline PGIT1: Our organization have capacity to identify shortage of qualified IT professionals & 0.976 & 0.968 & 0.979 & 0.941 \\
\hline PGIT2: Our organizations have capacity to identify lack of resources in hardware and software. & 0.958 & & & \\
\hline $\begin{array}{l}\text { PGIT3: Our organizations have capacity to identify shortage of quick adaptation to IT technology } \\
\text { change. }\end{array}$ & 0.975 & & & \\
\hline PRCA1: organization reduces cost of hiring IT staff compared with In-house Installation. & 0.835 & 0.853 & 0.911 & 0.774 \\
\hline $\begin{array}{l}\text { PRCA2: Predictable cost in using information system within the contract period of the online human } \\
\text { resource services. }\end{array}$ & 0.895 & & & \\
\hline $\begin{array}{l}\text { PRCA3: Reduction in the cost of enhancing IT applications with solution providers instead of traditional } \\
\text { In-house Installation of information system. }\end{array}$ & 0.907 & & & \\
\hline
\end{tabular}


Table 1. Continued

\begin{tabular}{|c|c|c|c|c|}
\hline Constructs/Items & Loadings & $(\boldsymbol{\alpha})$ & $\mathbf{C R}$ & AVE \\
\hline $\begin{array}{l}\text { PRSQ1: Use of information system in organizations can provide high security for data exchange, data } \\
\text { storage, data back-up, data restoration, and disaster recovery plan. }\end{array}$ & 0.848 & 0.775 & 0.853 & 0.594 \\
\hline $\begin{array}{l}\text { PRSQ2: Use of information system in organizations can provide proper and ease of use of application } \\
\text { features to support our business operations. }\end{array}$ & 0.777 & & & \\
\hline $\begin{array}{l}\text { PRSQ3: Use of information system in organizations can provide responsive and flexible services to meet } \\
\text { our company's needs. }\end{array}$ & 0.765 & & & \\
\hline $\begin{array}{l}\text { PRSQ4: Use of information system in organizations can provide reliable, readily available, and scalable } \\
\text { services. }\end{array}$ & 0.684 & & & \\
\hline TECH1: I would trust on information system provided by my organization to achieve tasks. & 0.913 & 0.899 & 0.930 & 0.768 \\
\hline $\begin{array}{l}\text { TECH2: I would prefer to use information system provided by my organization instead of manual } \\
\text { operation to achieve organizational tasks. }\end{array}$ & 0.856 & & & \\
\hline $\begin{array}{l}\text { TECH3: I am concerned that my personal data is not being shared with third parties without my } \\
\text { agreement. }\end{array}$ & 0.866 & & & \\
\hline $\begin{array}{l}\text { TECH4: I trust on technology provided by my organization and secure that data will not be shared with } \\
\text { third parties without my consent. }\end{array}$ & 0.870 & & & \\
\hline
\end{tabular}

Table 2. Discriminant validity using Fornell and Larcker's Criterion

\begin{tabular}{|l|l|l|l|l|l|l|l|l|l|l|}
\hline \multicolumn{1}{|c|}{$\#$} & ASGF & CLED & COMP & EMSE & INNO & ORGP & PGIT & PRCA & PRSQ & TECH \\
\hline ASGF & $\boldsymbol{0 . 8 8 1}$ & & & & & & & & & \\
\hline CLED & 0.019 & $\boldsymbol{0 . 8 4 4}$ & & & & & & & & \\
\hline COMP & 0.467 & 0.053 & $\boldsymbol{0 . 8 6 6}$ & & & & & & & \\
\hline EMSE & 0.459 & 0.016 & 0.273 & $\boldsymbol{0 . 8 9 9}$ & & & & & & \\
\hline INNO & 0.437 & 0.104 & 0.258 & 0.182 & $\mathbf{0 . 9 0 0}$ & & & & & \\
\hline ORGP & 0.406 & 0.133 & 0.317 & 0.214 & 0.213 & $\mathbf{0 . 9 0 9}$ & & & & \\
\hline PGIT & 0.771 & 0.019 & 0.296 & 0.323 & 0.280 & 0.281 & $\mathbf{0 . 9 7 0}$ & & & \\
\hline PRCA & 0.708 & 0.013 & 0.325 & 0.408 & 0.351 & 0.404 & 0.521 & $\boldsymbol{0 . 8 8 0}$ & & \\
\hline PRSQ & 0.150 & 0.001 & 0.107 & 0.002 & 0.108 & 0.039 & 0.030 & 0.087 & $\boldsymbol{0 . 7 7 1}$ & \\
\hline TECH & 0.658 & 0.056 & 0.453 & 0.295 & 0.376 & 0.358 & 0.516 & 0.582 & 0.096 & $\boldsymbol{0 . 8 7 7}$ \\
\hline
\end{tabular}

Note: Bold values indicate the square root of AVE of each construct

\subsection{Structural Model}

The measurement model confirms that constructs are reliable and measure distinct concepts. Therefore, structural model estimates causal relationship between two constructs. In order to confirm lateral collinearity of the constructs the criterion is that the inner variance inflation factor should be less than 3.3 as suggested by Samar Rahi and Abd. Ghani (2019b). Findings of the analysis showed that all VIF values are lower than 3.3 indicated that this study is free from multicollinearity issues and adequate for further analysis. The values of variance inflation factor can be sees in Table 5 . 
Table 3. Cross Loadings

\begin{tabular}{|c|c|c|c|c|c|c|c|c|c|c|}
\hline$\#$ & ASGF & CLED & COMP & EMSE & INNO & ORGP & PGIT & PRCA & PRSQ & TECH \\
\hline ASGF1 & 0.853 & -0.035 & 0.318 & 0.332 & 0.335 & 0.269 & 0.913 & 0.579 & 0.101 & 0.580 \\
\hline ASGF2 & 0.893 & 0.014 & 0.471 & 0.413 & 0.440 & 0.435 & 0.545 & 0.632 & 0.146 & 0.560 \\
\hline ASGF3 & 0.896 & -0.029 & 0.451 & 0.473 & 0.381 & 0.374 & 0.562 & 0.663 & 0.152 & 0.597 \\
\hline CLED1 & -0.030 & 0.816 & 0.031 & 0.017 & -0.092 & 0.116 & -0.022 & -0.013 & 0.010 & 0.051 \\
\hline CLED2 & 0.020 & 0.834 & 0.058 & 0.009 & -0.094 & 0.105 & 0.023 & 0.042 & 0.037 & 0.066 \\
\hline CLED3 & -0.035 & 0.882 & 0.046 & 0.015 & -0.077 & 0.115 & -0.045 & 0.006 & -0.046 & 0.028 \\
\hline COMP1 & 0.396 & 0.063 & 0.912 & 0.201 & 0.225 & 0.280 & 0.245 & 0.254 & 0.104 & 0.382 \\
\hline COMP2 & 0.494 & 0.045 & 0.838 & 0.327 & 0.225 & 0.278 & 0.354 & 0.379 & 0.090 & 0.473 \\
\hline COMP3 & 0.412 & 0.049 & 0.941 & 0.231 & 0.270 & 0.294 & 0.229 & 0.275 & 0.114 & 0.389 \\
\hline COMP4 & 0.248 & 0.019 & 0.762 & 0.130 & 0.149 & 0.239 & 0.136 & 0.152 & 0.047 & 0.272 \\
\hline EMSE1 & 0.415 & 0.035 & 0.284 & 0.867 & 0.134 & 0.208 & 0.329 & 0.353 & 0.000 & 0.271 \\
\hline EMSE2 & 0.423 & 0.010 & 0.238 & 0.929 & 0.187 & 0.181 & 0.279 & 0.398 & -0.016 & 0.273 \\
\hline EMSE3 & 0.399 & -0.001 & 0.211 & 0.899 & 0.169 & 0.189 & 0.261 & 0.348 & 0.023 & 0.250 \\
\hline INNO1 & 0.375 & -0.093 & 0.140 & 0.161 & 0.806 & 0.128 & 0.374 & 0.311 & 0.095 & 0.352 \\
\hline INNO2 & 0.436 & -0.091 & 0.287 & 0.156 & 0.955 & 0.228 & 0.228 & 0.326 & 0.112 & 0.347 \\
\hline INNO3 & 0.415 & -0.091 & 0.262 & 0.184 & 0.935 & 0.227 & 0.240 & 0.337 & 0.087 & 0.343 \\
\hline INNO4 & 0.332 & -0.099 & 0.227 & 0.152 & 0.895 & 0.173 & 0.162 & 0.282 & 0.095 & 0.308 \\
\hline ORGP1 & 0.351 & 0.112 & 0.244 & 0.188 & 0.154 & 0.941 & 0.254 & 0.367 & 0.023 & 0.322 \\
\hline ORGP2 & 0.419 & 0.108 & 0.376 & 0.213 & 0.285 & 0.874 & 0.258 & 0.411 & 0.056 & 0.368 \\
\hline ORGP3 & 0.330 & 0.145 & 0.232 & 0.179 & 0.129 & 0.910 & 0.252 & 0.315 & 0.024 & 0.277 \\
\hline PGIT1 & 0.752 & -0.018 & 0.299 & 0.306 & 0.285 & 0.283 & 0.976 & 0.503 & 0.041 & 0.535 \\
\hline PGIT2 & 0.749 & -0.028 & 0.294 & 0.315 & 0.266 & 0.270 & 0.958 & 0.529 & 0.000 & 0.478 \\
\hline PGIT3 & 0.741 & -0.009 & 0.268 & 0.319 & 0.263 & 0.265 & 0.975 & 0.485 & 0.046 & 0.489 \\
\hline PRCA1 & 0.592 & 0.006 & 0.198 & 0.296 & 0.270 & 0.256 & 0.651 & 0.835 & 0.048 & 0.523 \\
\hline PRCA2 & 0.628 & 0.036 & 0.336 & 0.367 & 0.353 & 0.431 & 0.350 & 0.895 & 0.095 & 0.483 \\
\hline PRCA3 & 0.648 & -0.007 & 0.317 & 0.408 & 0.301 & 0.373 & 0.389 & 0.907 & 0.086 & 0.531 \\
\hline PRSQ1 & 0.145 & 0.057 & 0.101 & -0.001 & 0.072 & 0.024 & 0.053 & 0.073 & 0.848 & 0.059 \\
\hline PRSQ2 & 0.105 & 0.029 & 0.062 & 0.032 & 0.145 & 0.067 & -0.032 & 0.132 & 0.777 & 0.063 \\
\hline PRSQ3 & 0.120 & -0.079 & 0.087 & -0.015 & 0.086 & 0.019 & 0.035 & 0.018 & 0.765 & 0.088 \\
\hline PRSQ4 & 0.076 & -0.030 & 0.075 & -0.011 & 0.023 & 0.012 & 0.026 & 0.049 & 0.684 & 0.103 \\
\hline ТЕCH1 & 0.584 & 0.029 & 0.332 & 0.224 & 0.309 & 0.275 & 0.607 & 0.511 & 0.054 & 0.913 \\
\hline ТЕСН2 & 0.593 & 0.069 & 0.495 & 0.287 & 0.390 & 0.383 & 0.320 & 0.531 & 0.147 & 0.856 \\
\hline ТЕСН3 & 0.593 & 0.053 & 0.475 & 0.347 & 0.312 & 0.364 & 0.351 & 0.532 & 0.087 & 0.866 \\
\hline ТЕCH4 & 0.530 & 0.046 & 0.272 & 0.164 & 0.304 & 0.222 & 0.545 & 0.461 & 0.045 & 0.870 \\
\hline
\end{tabular}


Table 4. Heterotrait-Monotrait Ratio (HTMT)

\begin{tabular}{|l|l|l|l|l|l|l|l|l|l|l|}
\hline & ASGF & CLED & COMP & EMSE & INNO & ORGP & PGIT & PRCA & PRSQ & TECH \\
\hline ASGF & 0.000 & & & & & & & & & \\
\hline CLED & 0.045 & & & & & & & & & \\
\hline COMP & 0.514 & 0.061 & & & & & & & & \\
\hline EMSE & 0.530 & 0.029 & 0.289 & & & & & & & \\
\hline INNO & 0.490 & 0.122 & 0.274 & 0.202 & & & & & & \\
\hline ORGP & 0.463 & 0.158 & 0.347 & 0.240 & 0.227 & & & & & \\
\hline PGIT & 0.840 & 0.041 & 0.300 & 0.349 & 0.296 & 0.302 & & & & \\
\hline PRCA & 0.829 & 0.037 & 0.349 & 0.468 & 0.394 & 0.457 & 0.580 & & & \\
\hline PRSQ & 0.178 & 0.080 & 0.121 & 0.030 & 0.125 & 0.050 & 0.054 & 0.108 & & \\
\hline TECH & 0.748 & 0.067 & 0.484 & 0.327 & 0.412 & 0.392 & 0.557 & 0.664 & 0.120 & 0.000 \\
\hline
\end{tabular}

Note: Heterotrait-Monotrait Ratio (HTMT) discriminate at (HTMT <0.9/ HTMT <0.85)

Table 5. Variance Inflation Factor Analysis

\begin{tabular}{|l|l|l|}
\hline \multicolumn{1}{|c|}{ Constructs } & Achieving strategic goal of the firm & Organizational Performance \\
\hline Achieving strategic goal of the firm & & 1.000 \\
\hline Cost Leadership & & 1.000 \\
\hline Compatibility & 1.313 & \\
\hline Employee Self-efficacy & 1.253 & \\
\hline Innovativeness & 1.221 & \\
\hline Perceived gap in IT capabilities & 1.549 & \\
\hline Perceived cost advantage & 1.839 & \\
\hline Perceived service quality & 1.025 & \\
\hline Trust in the technology & 1.905 & \\
\hline
\end{tabular}

Table 6. Hypothesis testing

\begin{tabular}{|l|l|l|l|l|l|c|}
\hline Hypothesis & \multicolumn{1}{|c|}{ Relationship } & Direct effect $(\boldsymbol{\beta})$ & Standard Deviation & T Statistics & P Values & Results \\
\hline H1 & COMP -> ASGF & 0.120 & 0.036 & $3.316^{* *}$ & 0.001 & Supported \\
\hline H2 & INNO - > ASGF & 0.106 & 0.031 & $3.431^{* *}$ & 0.001 & Supported \\
\hline H3 & TECH -> ASGF & 0.132 & 0.047 & $2.840^{* *}$ & 0.005 & Supported \\
\hline H4 & PGIT -> ASGF & 0.462 & 0.055 & $8.336^{* * *}$ & 0.000 & Supported \\
\hline H5 & EMSE -> ASGF & 0.112 & 0.034 & $3.266^{* *}$ & 0.001 & Supported \\
\hline H6 & PRSQ -> ASGF & 0.076 & 0.024 & $3.185^{* *}$ & 0.002 & Supported \\
\hline H7 & PRCA -> ASGF & 0.262 & 0.057 & $4.566^{* * *}$ & 0.000 & Supported \\
\hline H8 & ASGF -> ORGP & 0.409 & 0.059 & $6.957^{* * *}$ & 0.000 & Supported \\
\hline
\end{tabular}

Note: ${ }^{*} p<0.05 ;{ }^{* *} p<0.01 ;{ }^{* * *} p<0.001$ (one-tailed) 


\subsubsection{Hypothesis Testing}

The structural model of this study is assessed with beta value, $t$-statistics and significance level of the study. In addition to that, bootstrapping method is opted with re-sample of 1000 from original sample (Samar Rahi \& Abd. Ghani, 2018; Yamin \& Alyoubi, 2020). Table 6 exhibits hypothesised relationship with beta value, t-statistics and significance level of the constructs.

As depicted in Table 6 the relationship between compatibility and achieving strategic goal of the firm was found significant and supported by $\mathrm{H} 1$ : $(\beta=0.120$, t-value 3.316 , significance $\mathrm{p}<0.001)$. Innovativeness had significant influence on achieving strategic goal of the firm and supported by $\mathrm{H} 2$ : $(\beta=0.106$, t-value 3.431, significance $\mathrm{p}<0.001)$. The relationship between trust in the technology was also found significant and supported by $\mathrm{H} 3$ : $(\beta=0.132$, t-value 2.840 , significance $\mathrm{p}<0.005)$. Similarly, perceived gap in IT capabilities had showed significant influence on achieving strategic goal of the firm and supported by $\mathrm{H} 4$ : $(\beta=0.462$, $\mathrm{t}$-value 8.336 , significance $\mathrm{p}<0.001)$. Employee self-efficacy had showed positive impact on achieving strategic goal of the firm and supported by H5: $(\beta=0.112$, $\mathrm{t}$-value 3.266, significance $\mathrm{p}<0.001)$. Perceived service quality had showed significant influence on achieving strategic goal of the firm and supported by H6: $(\beta=0.076$, t-value 3.185, significance $\mathrm{p}<$ $0.002)$. The relationship between perceived cost advantage and achieving strategic goal of the firm was statistically confirmed and supported by $\mathrm{H} 7$ : $(\beta=0.262$, t-value 4.566 , significance $\mathrm{p}<0.000)$. Finally, H8 is confirmed wherein achieving strategic goal of the firm had positive and significant influence on organizational performance and supported by $(\beta=0.409$, t-value 6.957 , significance $\mathrm{p}<$ 0.000). Results of the structural model using bootstrap method can be seen in the Appendix. These findings confirmed that the extension of diffusion of innovation model (DOI) in human resource context is appropriate and significantly contributes to achieving strategic goal of the firm and boost organizational performance.

\subsubsection{Effect Size $\left(f^{2}\right)$, Predictive Relevance $Q^{2}$ and Coefficient of Determination $R^{2}$}

The current study introduces an extended diffusion of innovation model to investigate strategic goal of the firm and overall organization performance. The first endogenous construct namely achieving strategic goal of the firm was jointly predicted by compatibility, innovativeness, trust in technology, perceived gap in IT capabilities, employee self-efficacy, perceived service quality and perceived cost advantage and explained $R^{2} 79.4 \% \%$ variance in achieving strategic goal of the firm. On the flip side organizational performance is predicted by achieving strategic goal of the firm and cost leadership and explained $R^{2} 20.7 \%$ variance in organizational performance. These findings confirmed that model have substantial power to predict firm strategic goals and organizational performance. Although coefficient of determination had showed substantial variance, the individual variance of each exogenous variable is yet to be confirmed with effect size analysis (M. Yamin, 2020). Effect size analysis showed that perceived gap in IT capabilities had substantial effect size in predicting strategic goal of the firm. Perceived cost advantage had the medium size effect. Therefore, all other constructs had showed small effect size in predicting firm strategic goals. Concerning with organizational performance, achieving strategic goal had medium whereas cost leadership had showed small effect size on organizational performance. Finally, the predictive relevance of the model was tested with blind folding procedure $Q^{2}$ which is in line with S. Samar, Ghani, and Alnaser (2017) and S Rahi, Ghani, Alnaser, and Ngah (2018). The predictive relevance test suggested that the values of $Q^{2}$ should be greater than 0 , reflecting adequate predictive relevance of the model (Samar Rahi, Ghani, \& Alnaser, 2017; R. Samar, Norjaya, \& Feras, 2017; M. A. Y. Yamin, 2020). Finding of the predictive analysis revealed that the newly developed model have substantial predictive relevance $Q^{2} 58.1 \%$ when predicting firm strategic goals. Similarly, extended model had showed adequate predictive relevance $Q^{2} \quad 15.7 \%$ when measuring organizational performance. The results of the predictive relevance, effect size analysis and coefficient of determination are exhibited in Table 7. 
Table 7. Effect size analysis $\left(f^{2}\right)$ and predictive relevance $Q^{2}$

\begin{tabular}{|c|c|c|c|c|}
\hline \multicolumn{5}{|c|}{ Achieving strategic goal of the firm (ASGF) } \\
\hline Constructs & $\boldsymbol{R}^{2}$ & $Q^{2}$ & $\left(\boldsymbol{f}^{2}\right)$ & Size \\
\hline Achieving strategic goal of the firm (ASGF) & $79.4 \%$ & $58.1 \%$ & & \\
\hline Compatibility (COMP) & & & 0.053 & Small \\
\hline Employee Self-efficacy (EMSE) & & & 0.049 & Small \\
\hline Innovativeness (INNO) & & & 0.045 & Small \\
\hline Perceived gap in IT capabilities (PGIT) & & & 0.669 & Substantial \\
\hline Perceived cost advantage (PRCA) & & & 0.181 & Medium \\
\hline Perceived service quality (PRSQ) & & & 0.027 & Small \\
\hline Trust in the technology (TECH) & & & 0.044 & Small \\
\hline \multicolumn{5}{|l|}{ Organizational Performance (ORGP) } \\
\hline Constructs & $\boldsymbol{R}^{2}$ & $\boldsymbol{Q}^{2}$ & $\left(\boldsymbol{f}^{2}\right)$ & Size \\
\hline Organizational Performance (ORGP) & $20.7 \%$ & $15.7 \%$ & & \\
\hline Achieving strategic goal of the firm (ASGF) & & & 0.211 & Medium \\
\hline Cost Leadership (CLED) & & & 0.025 & Small \\
\hline
\end{tabular}

Note: $f^{2} \quad 0.02$, Small; 0.15 , Medium; 0.35 , Substantial

\subsection{Moderating Analysis}

Apart of diffusion of innovation theory extension, the current study examined the role of cost leadership as moderating variable between achieving strategic goal of the firm and organizational performance. Therefore, the current study proposed that "The positive relationship between achieving strategic goal of the firm and organizational performance will be stronger when cost leadership is higher". The proposed hypothesis is tested with structural model. Within structural model, product-indicator approach is used as suggested by Samar Rahi (2015, 2016a). Results of the moderating analysis showed that the interaction effect between cost leadership and achieving strategic goal of the firm is significant and supported by H9: $(\beta=0.153, \mathrm{t}-2.202, \mathrm{p}<0.001)$. These findings confirmed that strategic goal of the firm and cost leadership altogether influence on organizational performance. Findings of the moderating analysis with interaction effect of strategic goal of the firm and cost leadership are shown in Figure 2.

\section{DISCUSSION}

The research model of this study extends the diffusion of innovation theory (DOI) in organizational context and revealed that compatibility, innovativeness, trust in technology, perceived gap in IT capabilities, employee self-efficacy, perceived service quality and perceived cost advantage explained $R^{2} 79.4 \% \%$ variance in achieving strategic goal of the firm. In addition to that organizational performance is predicted by achieving strategic goal of the firm and cost leadership and explained 


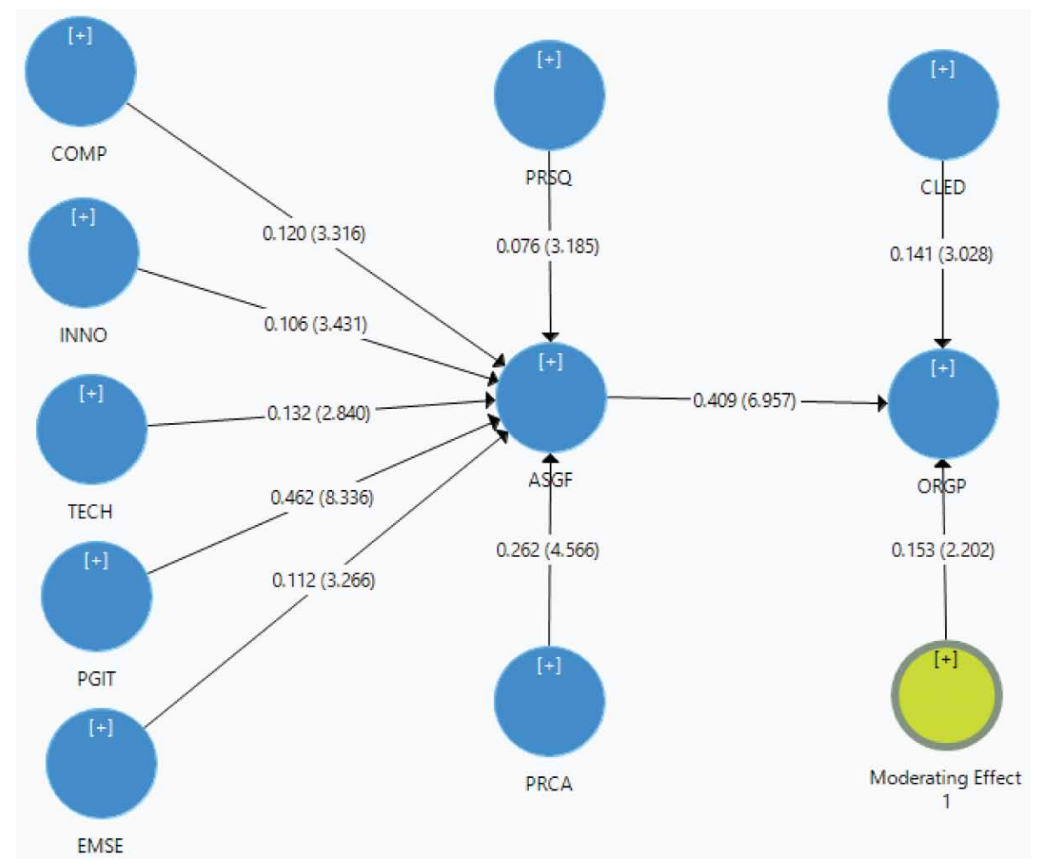

$R^{2} 20.7 \%$ variance in organizational performance. These findings confirmed that newly developed research model as depicted in Fig.1 is appropriate and significantly contributes to achieving strategic goal of the firm which in turn boost organizational performance.Table 6 showed causal relationships between exogenous and endogenous variables. The relationship between compatibility and achieving strategic goal of the firm is found significant and in line with Karahanna et al. (2006); Oliveira et al. (2016); Samar Rahi and Abd. Ghani (2018); Rogers (1962, 2003); Zhao and de Pablos (2011). Innovativeness had significant influence on achieving strategic goal of the firm and consistent with Zhao and de Pablos (2011). Trust in the technology had significant influence on achieving strategic goal of the firm and followed earlier studies Fuller et al. (2009); Komiak and Benbasat (2006); Pavlou (2003); Salisbury et al. (2001). Extending to this perceived gap in IT capabilities had showed significant influence on achieving strategic goal of the firm and in line with Jayatilaka et al. (2003); Loebbecke and Huyskens (2006); Smith and Kumar (2004).

Similarly, employee self-efficacy had showed positive impact on achieving strategic goal of the firm and in line with Bandura et al. (1999); Choi (2004); D. Wang et al. (2008). Perceived service quality had showed significant influence on achieving strategic goal of the firm and in line with Ghani et al. (2017); R. Samar and Mazuri (2019b). The relationship between perceived cost advantage and achieving strategic goal of the firm was statistically confirmed and in line with Benlian and Hess (2011); Martens and Teuteberg (2012); Smith and Kumar (2004). Concerning with achieving strategic goal of the firm and organizational performance, findings of the structural model showed that achieving strategic goal significantly influence on organizational performance and in line with Chakraborty and Biswas (2019); Dobre (2013); Trybou et al. (2017). Finally, the moderating role of cost leadership was confirmed between achieving strategic goal of the firm and organizational performance. Interaction effect confirmed that "the positive relationship between achieving strategic goal of the firm and organizational performance will be stronger when cost Leadership is higher". Therefore, managers and policy makers should focus underpinning factors which includes compatibility, innovativeness, trust in technology, perceived gap in IT capabilities, employee self-efficacy, perceived service 
quality, perceived cost advantage and cost leadership in order to achieve strategic goal of the firm and organizational performance in Public sector organizations.

\section{CONCLUSION}

In this dynamic world, organizations are taking help from artificial intelligence using information technology. The old brick-and-mortar documentation system is obsoleted and now organizations are shifting into electronic documentation using information technology. Therefore, understanding the importance of information system in human resource departments is vital for organizational success. In this essence, the current study develops an extended diffusion of innovation model to examine strategic goal of the firm and overall organization performance. Strategic goal of the firm is jointly predicted by compatibility, innovativeness, trust in technology, perceived gap in IT capabilities, employee self-efficacy, perceived service quality and perceived cost advantage and explained $R^{2}$ $79.4 \% \%$ variance in achieving strategic goal of the firm. In extended model, the organizational performance is predicted by achieving strategic goal of the firm and cost leadership and explained $R^{2} 20.7 \%$ variance in organizational performance. Moving further, the effect size analysis showed that perceived gap in IT capabilities had substantial effect size in predicting strategic goal of the firm therefore perceived cost advantage had the medium size effect. The predictive relevance of the model is tested with blind folding procedure $Q^{2}$, test indicated that the newly developed model have substantial predictive relevance $Q^{2} 58.1 \%, 15.7 \%$ when predicting firm strategic goals and organizational performance respectively. The importance performance matrix analysis (IPMA) is applied in this study by selecting organizational performance as outcome variable. Results of the IPMA analysis showed that strategic goal of the firm had the highest importance value therefore perceived gap in IT capabilities, cost leadership and perceived cost advantage had intermediate level of importance to predict organizational performance. Findings showed that strategic goal of the firm, perceived gap in IT capabilities, cost leadership and perceived cost advantage are the most influential constructs that managers need to take into consideration. This research extends the body of knowledge by adding moderating role of cost leadership between achieving strategic goal of the firm and organizational performance. Finding of the moderating analysis is confirmed that the positive relationship between achieving strategic goal of the firm and organizational performance will be stronger when cost leadership is higher. Thus, managers and policy makers should focus on factors such as trust in technology, strategic goal of the firm, perceived gap in IT capabilities, cost leadership and perceived cost advantage in order to boost the organizational performance.

\subsection{Limitations and Future Research Directions}

Although, the current study augments to human resource and information system literature and provides several implications to theory and practice, it is important to highlights limitations for future research. There are two major limitations of this study foremost this study is cross-sectional and examines employee behaviour at one point of time which may vary in longitudinal study. Therefore, future research may conduct in longitudinal context while using qualitative research methods. Secondly, the present study is incorporated employee observations from only public sector organizations. Therefore, adding employees observations from private sector could reveal interesting findings. Finally, this study is in Middle East context, replication of this research model in Asian countries is important for the generalizability of the model.

\section{ACKNOWLEDGEMENT}

This work was funded by the University of Jeddah, Saudi Arabia, under grant No. (UJ-20-060-DR). the authors, therefore, acknowledge with thank the university of Jeddah technical and financial support. 


\section{REFERENCES}

Al-Alawi, A. I., \& Al-Bassam, S. A. (2019). Evaluation of telecommunications regulatory practice in the Kingdom of Bahrain: Development and challenges. International Journal of Business Information Systems, 31(2), 282-303. doi:10.1504/IJBIS.2019.100282

Al-Ammary, J. H., Al-Doseri, S., Al-Blushi, Z., Al-Blushi, N., \& Aman, M. (2019). Strategic information systems planning in Kingdom of Bahrain: Factors and impact of adoption. International Journal of Business Information Systems, 30(4), 387-410. doi:10.1504/IJBIS.2019.099303

Aldholay, A., Isaac, O., Abdullah, Z., Abdulsalam, R., \& Al-Shibami, A. H. (2018). An extension of Delone and McLean IS success model with self-efficacy: Online learning usage in Yemen. The International Journal of Information and Learning Technology, 35(4), 285-304. doi:10.1108/IJILT-11-2017-0116

Alnaser, F., Ghani, M., \& Rahi, S. (2017). The Impact of SERVQUAL Model and Subjective Norms on Customer's Satisfaction and Customer Loyalty in Islamic Banks: A Cultural Context. Int J Econ Manag Sci, 6(5), 455.

Alnaser, F., Ghani, M., \& Rahi, S. (2018). Service quality in Islamic banks: The role of PAKSERV model, customer satisfaction and customer loyalty. Accounting, 4(2), 63-72. doi:10.5267/j.ac.2017.8.001

Aubert, B. A., Beaurivage, G., Croteau, A.-M., \& Rivard, S. (2009). Firm strategic profile and IT outsourcing Information Systems Outsourcing. Springer.

Auxilia, M., Raja, K., \& Kannan, K. (2020). Cloud-Based Access Control Framework for Effective Role Provisioning in Business Application. International Journal of System Dynamics Applications, 9(1), 63-80. doi:10.4018/IJSDA.2020010104

Bandura, A., Freeman, W., \& Lightsey, R. (1999). Self-efficacy: The exercise of control. Springer.

Benlian, A., \& Hess, T. (2011). Opportunities and risks of software-as-a-service: Findings from a survey of IT executives. Decision Support Systems, 52(1), 232-246. doi:10.1016/j.dss.2011.07.007

Bose, R., \& Luo, X. (2011). Integrative framework for assessing firms' potential to undertake Green IT initiatives via virtualization-A theoretical perspective. The Journal of Strategic Information Systems, 20(1), 38-54. doi:10.1016/j.jsis.2011.01.003

Chakraborty, D., \& Biswas, W. (2019). Evaluating the impact of human resource planning programs in addressing the strategic goal of the firm: An organizational perspective. Journal of Advances in Management Research.

Choi, J. N. (2004). Individual and contextual predictors of creative performance: The mediating role of psychological processes. Creativity Research Journal, 16(2-3), 187-199. doi:10.1080/10400419.2004.9651452

Daud Norzaidi, M., Choy Chong, S., Murali, R., \& Intan Salwani, M. (2007). Intranet usage and managers' performance in the port industry. Industrial Management \& Data Systems, 107(8), 1227-1250. doi:10.1108/02635570710822831

Dehning, B., Richardson, V. J., \& Zmud, R. W. (2007). The financial performance effects of IT-based supply chain management systems in manufacturing firms. Journal of Operations Management, 25(4), 806-824. doi:10.1016/j.jom.2006.09.001

Delone, W. H., \& McLean, E. R. (2003). The DeLone and McLean model of information systems success: A tenyear update. Journal of Management Information Systems, 19(4), 9-30. doi:10.1080/07421222.2003.11045748

Dobre, O. I. (2013). Employee motivation and organizational performance. Review of Applied Socio-Economic Research, 5(1), 53-60.

Dubey, A., \& Wagle, D. (2007). Delivering software as a service. The McKinsey Quarterly, 6, 2007.

Elharakany, R. A., Moscardini, A., Khalifa, N. M., \& Abd Elghany, M. M. (2018). Modelling the Effect on Quality of Information and Communications Technology (ICT) facilities in Higher Education: Case Study-Egyptian Universities. International Journal of System Dynamics Applications, 7(3), 1-30. doi:10.4018/IJSDA.2018070101

Fan, M., Kumar, S., \& Whinston, A. B. (2009). Short-term and long-term competition between providers of shrink-wrap software and software as a service. European Journal of Operational Research, 196(2), 661-671. doi:10.1016/j.ejor.2008.04.023 
Fornell, C., \& Larcker, D. F. (1981). Structural Equation Models With Unobservable Variables and Measurement Error: Algebra and Statistics. JMR, Journal of Marketing Research, 18(3), 382-388. doi:10.1177/002224378101800313

Fuller, M. A., Serva, M. A., \& Baroudi, J. (2009). Clarifying the integration of trust and TAM in e-commerce environments: Implications for systems design and management. IEEE Transactions on Engineering Management, 57(3), 380-393.

Galli, B. J. (2020). Continuous Technological Improvement Using Systems Engineering Principles to Achieve Sustainability: An Investigation Into Related Literature. International Journal of System Dynamics Applications, 9(3), 1-25. doi:10.4018/IJSDA.2020070101

Ghani, M. A., Rahi, S., Yasin, N. M., \& Alnaser, F. M. (2017). Adoption of Internet Banking: Extending the Role of Technology Acceptance Model (TAM) with E-Customer Service and Customer Satisfaction. World Applied Sciences Journal, 35(9), 1918-1929.

Gold, A. H., \& Arvind Malhotra, A. H. S. (2001). Knowledge management: An organizational capabilities perspective. Journal of Management Information Systems, 18(1), 185-214. doi:10.1080/07421222.2001.11045669

Grover, V., Cheon, M., \& Teng, J. T. (1994). An evaluation of the impact of corporate strategy and the role of information technology on IS functional outsourcing. European Journal of Information Systems, 3(3), 179-190. doi:10.1057/ejis.1994.19

Ha, S. T., \& Lo, M. C. (2018). An empirical examination of knowledge management and organisational performance among Malaysian manufacturing SMEs. International Journal of Business Innovation and Research, 17(1), 23-37. doi:10.1504/IJBIR.2018.094196

Han, S. (2003). Individual adoption of information systems in organizations: A literature review of technology acceptance model. Turku Centre for Computer Science. TUCS.

Haselmann, T., \& Vossen, G. (2011). Software-as-a-service in small and medium enterprises: an empirical attitude assessment. Paper presented at the International Conference on Web Information Systems Engineering. doi:10.1007/978-3-642-24434-6_4

Heart, T., Pliskin, N., \& Tractinsky, N. (2004). Modeling intention to use an Application Service Provider. AMCIS 2004 Proceedings, 445.

Ho Cheong, J., \& Park, M.-C. (2005). Mobile internet acceptance in Korea. Internet Research, 15(2), 125-140. doi:10.1108/10662240510590324

Jayatilaka, B., Schwarz, A., \& Hirschheim, R. (2003). Determinants of ASP choice: An integrated perspective. European Journal of Information Systems, 12(3), 210-224. doi:10.1057/palgrave.ejis.3000466

Karahanna, E., Agarwal, R., \& Angst, C. M. (2006). Reconceptualizing compatibility beliefs in technology acceptance research. Management Information Systems Quarterly, 30(4), 781-804. doi:10.2307/25148754

Kaufmann, L., \& Schneider, Y. (2004). Intangibles: A synthesis of current research. Journal of Intellectual Capital, 5(3), 366-388. doi:10.1108/14691930410550354

Kiumarsi, S., Isa, S. M., Jayaraman, K., Amran, A., \& Hashemi, S. (2020). The effect of service innovation on service loyalty in post offices. International Journal of Business Innovation and Research, 21(1), 108-127. doi:10.1504/IJBIR.2020.104035

Kiveu, M. N., Namusonge, M., \& Muathe, S. (2019). Effect of innovation on firm competitiveness: The case of manufacturing SMEs in Nairobi County, Kenya. International Journal of Business Innovation and Research, 18(3), 307-327. doi:10.1504/IJBIR.2019.098251

Kline, R. (2011). Principles and Practice of Structural Equation Modeling (3rd ed.). Guilford Press.

Komiak, S. Y., \& Benbasat, I. (2006). The effects of personalization and familiarity on trust and adoption of recommendation agents. Management Information Systems Quarterly, 30(4), 941-960. doi:10.2307/25148760

Lee, S., \& Kim, K. (2007). Factors affecting the implementation success of Internet-based information systems. Computers in Human Behavior, 23(4), 1853-1880. doi:10.1016/j.chb.2005.12.001 
Liang, H., Saraf, N., Hu, Q., \& Xue, Y. (2007). Assimilation of enterprise systems: The effect of institutional pressures and the mediating role of top management. Management Information Systems Quarterly, 31(1), 59-87. doi: $10.2307 / 25148781$

Limam, N., \& Boutaba, R. (2010). Assessing software service quality and trustworthiness at selection time. IEEE Transactions on Software Engineering, 36(4), 559-574. doi:10.1109/TSE.2010.2

Loebbecke, C., \& Huyskens, C. (2006). What drives netsourcing decisions? An empirical analysis. European Journal of Information Systems, 15(4), 415-423. doi:10.1057/palgrave.ejis.3000621

Mahdi, O. R., \& Almsafir, M. K. (2014). The role of strategic leadership in building sustainable competitive advantage in the academic environment. Procedia: Social and Behavioral Sciences, 129, 289-296. doi:10.1016/j. sbspro.2014.03.679

Makokha, M. W., \& Ochieng, D. O. (2014). Assessing the Success of ICT's from a User Perspective: Case Study of Coffee Research Foundation, Kenya. Journal of Management and Strategy, 5(4), 46. doi:10.5430/jms.v5n4p46

Martens, B., \& Teuteberg, F. (2012). Decision-making in cloud computing environments: A cost and risk based approach. Information Systems Frontiers, 14(4), 871-893. doi:10.1007/s10796-011-9317-x

Mayayise, T. O., \& Osunmakinde, I. O. (2019). Connective intelligence to stay safe while shopping online for e-products and e-services on business-2-business and business-2-consumer websites. International Journal of Business Information Systems, 30(3), 348-372. doi:10.1504/IJBIS.2019.098247

Miles, R. E., Snow, C. C., Meyer, A. D., \& Coleman, H. J. Jr. (1978). Organizational strategy, structure, and process. Academy of Management Review, 3(3), 546-562. doi:10.5465/amr.1978.4305755 PMID:10238389

Miltgen, C. L., Popovič, A., \& Oliveira, T. (2013). Determinants of end-user acceptance of biometrics: Integrating the "Big 3" of technology acceptance with privacy context. Decision Support Systems, 56, 103-114. doi:10.1016/j. dss.2013.05.010

Mohammad Ali, Y. (2018). The mediating role of ethical organizational climate between HRM practices and HR outcomes in Public Sector of Saudi Arabia. International Journal of Business Excellence, O(0). Advance online publication. doi:10.1504/IJBEX.2019.10016985

Nikabadi, M. S., \& Hakaki, A. (2018). A dynamic model of effective factors on open innovation in manufacturing small and medium sized companies. International Journal of System Dynamics Applications, 7(1), 1-26. doi:10.4018/IJSDA.2018010101

Oliveira, T., Thomas, M., Baptista, G., \& Campos, F. (2016). Mobile payment: Understanding the determinants of customer adoption and intention to recommend the technology. Computers in Human Behavior, 61, $404-414$. doi:10.1016/j.chb.2016.03.030

Omamo, A. O., Rodrigues, A. J., \& Muliaro, W. J. (2020). A System Dynamics Model of Technology and Society: In the Context of a Developing Nation. International Journal of System Dynamics Applications, 9(2), 42-63. doi:10.4018/IJSDA.2020040103

Pavlou, P. A. (2003). Consumer acceptance of electronic commerce: Integrating trust and risk with the technology acceptance model. International Journal of Electronic Commerce, 7(3), 101-134. doi:10.1080/10864415.200 3.11044275

Porter, M. E. (1985). MILLAR, VE How information gives you competitive advantage. Harvard Business Review, 63(4), 149-160.

Rahi, S. (2015). Moderating role of brand image with relation to internet banking and customer loyalty: A case of branchless banking. Journal of Internet Banking and Commerce, 20(3). Advance online publication. doi:10.4172/1204-5357.1000131

Rahi, S. (2016a). Impact of Customer Perceived Value and Customers Perception of Public Relation on Customer Loyalty with Moderating Role of Brand Image. Journal of Internet Banking and Commerce, 21(2).

Rahi, S. (2016b). Impact of Customer Value, Public Relations Perception and Brand Image on Customer Loyalty in Services Sector of Pakistan. Arabian J Bus Manag Review, S2, 4.

Rahi, S. (2017). Structural Equation Modeling Using SmartPLS. CreateSpace Independent Publishing Platform. 
Rahi, S. (2018). Examining the Effects of Travel Constraints, Tourist Satisfaction and Website Image on Tourist Loyalty in Developing Countries Context. Economic and Social Development: Book of Proceedings, 478-487.

Rahi, S. (2018a). Research Design and Methods. CreateSpace Independent Publishing Platform.

Rahi, S. (2018b). Technology Adoption Issues in Banks. CreateSpace Independent Publishing Platform.

Rahi, S., \& Abd. Ghani, M. (2019a). Integration of expectation confirmation theory and self-determination theory in internet banking continuance intention. Journal of Science and Technology Policy Management. 10.1108/JSTPM-06-2018-0057

Rahi, S., \& Abd. Ghani, M. (2018). The role of UTAUT, DOI, perceived technology security and game elements in internet banking adoption. World Journal of Science. Technology and Sustainable Development, 15(4), 338-356. doi:10.1108/WJSTSD-05-2018-0040

Rahi, S., \& Abd. Ghani, M. (2019b). Investigating the role of UTAUT and e-service quality in internet banking adoption setting. The TQM Journal, 31(3), 491-506. doi:10.1108/TQM-02-2018-0018

Rahi, S., Abd.Ghani, M., \& Hafaz Ngah, A. (2019). Integration of unified theory of acceptance and use of technology in internet banking adoption setting: Evidence from Pakistan. Technology in Society, 58, 101120. doi:10.1016/j.techsoc.2019.03.003

Rahi, S., Alnaser, F. M., \& Ghani, M. A. (2019). Designing Survey Research: Recommendation for Questionnaire Development, Calculating Sample Size and Selecting Research Paradigms. Economic and Social Development: Book of Proceedings, 1157-1169.

Rahi, S., \& Ghani, M. (2016). Internet Banking, Customer Perceived Value and Loyalty: The Role of Switching Costs. J Account Mark, 5(4), 188. doi:10.4172/2168-9601.1000188

Rahi, S., Ghani, M., Alnaser, F., \& Ngah, A. (2018). Investigating the role of unified theory of acceptance and use of technology (UTAUT) in internet banking adoption context. Management Science Letters, 8(3), 173-186. doi:10.5267/j.msl.2018.1.001

Rahi, S., Ghani, M., \& Muhamad, F. (2017). Inspecting the Role of Intention to Trust and Online Purchase in Developing Countries. J Socialomics, 6(1). Advance online publication. doi:10.4172/2167-0358.1000191

Rahi, S., \& Ghani, M. A. (2018a). Investigating the Role of E-Service Quality and Brand Image in Internet Banking Acceptance Context with Structural Equation Modeling (SEM-PLS). Paper presented at the Economic and Social Development, 30th International Scientific Conference on Economic and Social.

Rahi, S., \& Ghani, M. A. (2018b). A Structural Equation Modeling (SEM-AMOS) for Investigating Brand Loyalty and Customer's Intention towards Adoption of Internet Banking Paper presented at the Economic and Social Development, 29th International Scientific Conference on Economic and Social.

Rahi, S., Ghani, M. A., \& Alnaser, F. M. (2017). The Influence of E-Customer Services and Perceived Value on Brand Loyalty of Banks and Internet Banking Adoption: A Structural Equation Model (SEM). Journal of Internet Banking and Commerce, 22(1), 1-18.

Rahi, S., Ghani, M. A., \& Ngah, A. H. (2020). Factors Propelling the Adoption of Internet Banking: The Role of E-Customer Service, Website Design, Brand Image and Customer Satisfaction. International Journal of Business Information Systems, O(0), 549. Advance online publication. doi:10.1504/IJBIS.2020.105870

Rahi, S., Othman Mansour, M. M., Alghizzawi, M., \& Alnaser, F. M. (2019). Integration of UTAUT model in internet banking adoption context. Journal of Research in Interactive Marketing, 13(3), 411-435. doi:10.1108/ JRIM-02-2018-0032

Ringle, C. M., Wende, S., \& Becker, J.-M. (2015). SmartPLS 3. Boenningstedt: SmartPLS GmbH.

Rogers. (1962). Diffusion of Innovations. Free Press of Glencoe.

Rogers. (2003). Diffusion of Innovations. Simon and Schuster.

Roper, S., Du, J., \& Love, J. H. (2006). Knowledge sourcing and innovation. Aston Business School Birmingham.

Ryan, B., \& Gross, N. C. (1943). The diffusion of hybrid seed corn in two Iowa communities. Rural Sociology, $8(1), 15$. 
Salisbury, W., Pearson, R., Pearson, A., \& Miller, D. (2001). Identifying barriers that keep shoppers off the world wide web: Developing a scale of perceived web security. Industrial Management \& Data Systems, 101(4), 165-176. doi:10.1108/02635570110390071

Samar, R., \& Mazuri, A. G. (2019a). Does gamified elements influence on user's intention to adopt internet banking with integration of UTAUT and General Self-Confidence? International Journal of Business Excellence, $O(0), 394$. Advance online publication. doi:10.1504/IJBEX.2019.102835

Samar, R., \& Mazuri, A. G. (2019b). Integration of DeLone \& McLean and Self-Determination Theory in internet banking continuance intention context. International Journal of Accounting and Information Management, 27(3).

Samar, R., Norjaya, M. Y., \& Feras, M. A. (2017). Measuring the role of website design, assurance, customer service and brand image towards customer loyalty and intention to adopt interent banking. Journal of Internet Banking and Commerce, 22(S8).

Samar, S., Ghani, M., \& Alnaser, F. (2017). Predicting customer's intentions to use internet banking: The role of technology acceptance model (TAM) in e-banking. Management Science Letters, 7(11), 513-524.

Seethamraju, R. (2015). Adoption of software as a service (SaaS) enterprise resource planning (ERP) systems in small and medium sized enterprises (SMEs). Information Systems Frontiers, 17(3), 475-492. doi:10.1007/ s10796-014-9506-5

Smith, M. A., \& Kumar, R. L. (2004). A theory of application service provider (ASP) use from a client perspective. Information \& Management, 41(8), 977-1002. doi:10.1016/j.im.2003.08.019

Swaiess, M., \& Yamin, M. A. (2019). Investigating Employee creative performance with integration of DeLone and McLean Information system success model and Technology acceptance model: The moderating role of Creative self-efficacy. International Journal of Business Excellence, $0(0), 10024168$. Advance online publication. doi:10.1504/IJBEX.2019.10024168

Teo, T. (2010). Examining the influence of subjective norm and facilitating conditions on the intention to use technology among pre-service teachers: A structural equation modeling of an extended technology acceptance model. Asia Pacific Education Review, 11(2), 253-262. doi:10.1007/s12564-009-9066-4

Trybou, J., Gemmel, P., Desmidt, S., \& Annemans, L. (2017). Fulfillment of administrative and professional obligations of hospitals and mission motivation of physicians. BMC Health Services Research, $17(1), 28$. doi:10.1186/s12913-017-1990-0 PMID:28086876

Venkatachalam, N., Fielt, E., Rosemann, M., \& Mathews, S. (2012). Small and medium enterprises sourcing software as a service-a dynamic perspective on IS capabilities. Small, 7, 15-2012.

Wang, D., Xu, L., \& Chan, H. C. (2008). Understanding users' continuance of Facebook: The role of general and specific computer self-efficacy. ICIS 2008 Proceedings, 168.

Wang, Y.-S., \& Liao, Y.-W. (2008). Assessing eGovernment systems success: A validation of the DeLone and McLean model of information systems success. Government Information Quarterly, 25(4), 717-733. doi:10.1016/j.giq.2007.06.002

Wixom, B. H., \& Todd, P. A. (2005). A theoretical integration of user satisfaction and technology acceptance. Information Systems Research, 16(1), 85-102. doi:10.1287/isre.1050.0042

Wu, F., Mahajan, V., \& Balasubramanian, S. (2003). An analysis of e-business adoption and its impact on business performance. Journal of the Academy of Marketing Science, 31(4), 425-447. doi:10.1177/0092070303255379

Xin, M., \& Levina, N. (2008). Software-as-a-service model: Elaborating client-side adoption factors. Proceedings of the 29th International Conference on Information Systems.

Yamin, M. (2020). Examining the role of transformational leadership and entrepreneurial orientation on employee retention with moderating role of competitive advantage. Management Science Letters, 10(2), 313-326. doi:10.5267/j.msl.2019.8.039

Yamin, M. A. Y. (2020). Examining the effect of organisational innovation on employee creativity and firm performance: Moderating role of knowledge sharing between employee creativity and employee performance. International Journal of Business Innovation and Research, 22(3), 447-467. doi:10.1504/IJBIR.2020.108009 
Yamin, M. A. Y., \& Alyoubi, B. A. (2020). Adoption of telemedicine applications among saudi citizens during covid-19 pandemic: An alternative health delivery system. Journal of Infection and Public Health, 13(12), 1845-1855. Advance online publication. doi:10.1016/j.jiph.2020.10.017 PMID:33172819

Zhao, J., \& de Pablos, P. O. (2011). Regional knowledge management: The perspective of management theory. Behaviour \& Information Technology, 30(1), 39-49. doi:10.1080/0144929X.2010.492240 


\section{APPENDIX}

Figure 3.

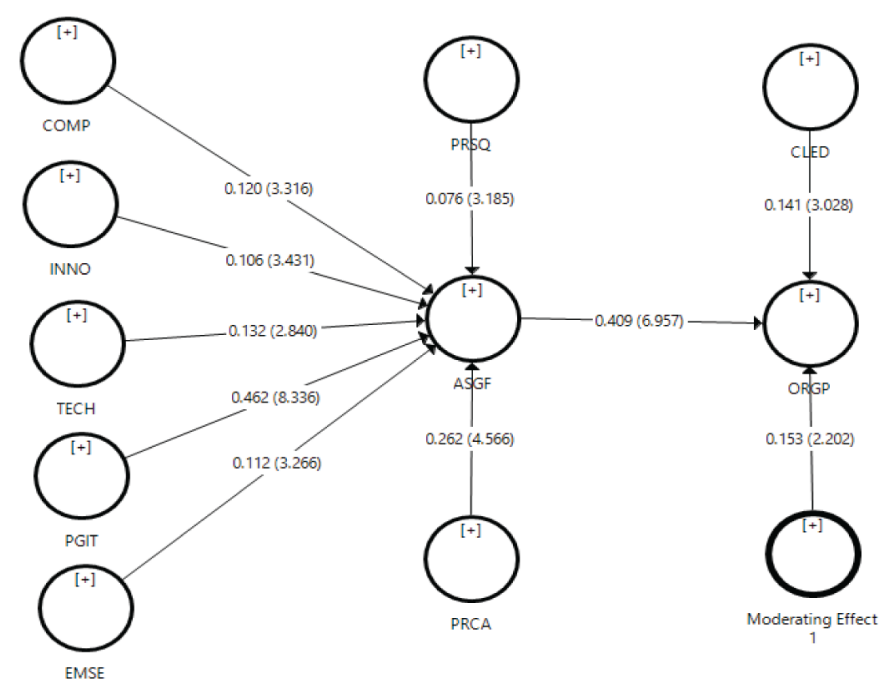

Bader A. Alyoubi College of Business, Department of Management Information Systems, University of Jeddah, Saudi Arabia. Google Scholar: https://scholar.google.com/citations?user=9J0ZU2gAAAAJ\&hl=ar.

Mohammed Ali Yousef Yamin is currently associate professor of department of human resources management in business collage at the University of Jeddah in the Kingdome of Saudi Arabia. Assistance professor of the business collage at al-Quds University in Palestine in the past. He also worked many administrative positions at human resources department and public relationship before he holds the doctoral degree in human resources and organizational behavior. He is the author of many articles on topic of his specialty. Google Scholar: https://scholar. google.com/citations?hl=en\&user=mh2nJ9EAAAAJ. 